\title{
Forord til Cognition/Kognition
}

\author{
KeN RAMSHØJ CHRISTENSEN \\ Institut for Sprog, Litteratur og Kultur, Aarhus Universitet, Danmark \\ Center for Funktionelt Integrativ Neurovidenskab, Aarhus \\ Universitetshospital, Danmark
}

\section{INDLEDNING}

Temaet for dette nummer af Tidsskrift for Sprogforskning er "Sprog og Kognition", titlen på Lingvistisk Forskningskollokvium på Statsbiblioteket, den 29. november 2007. Titlen dækker over nogle meget store områder og over mindst tre svære spørgsmål: Hvad er sprog? Hvad er kognition? Hvor er de i hjernen? Jeg vil her forsøge at give nogle meget korte svar som indledning til artiklerne der handler om interaktionen mellem sprog, kognition og hjerne.

\section{HVAD ER KOGNITION?}

Kognition er en teknisk betegnelse for tankevirksomhed og anvendes som oftest i betydningen "mental databehandling" (der er ikke nogen gode danske oversættelser af de engelske information processing og computation), men der er ikke udbredt enighed om hvad ordet præcist dækker over. Overordnet kan man dog sige at det er måden hjernen laver forudsigelser om verden på baseret på sanseindtryk, forudgående viden (herunder fysiske lovmæssigheder såsom tyngdekraft og kausalitet, hvordan mennesker, dyr og ting bevæger sig og interagerer), og rent subjektive følelsesmæssige erfaringer. Der er også andre faktorer i spil, såsom kønsforskelle i måden vi tænker på, og kulturelle forskelle i verdensopfattelse. Det følger af en sådan meget bred definition at kognition nødvendigvis involverer hele hjernen. Kognition er kort sagt hvad hjernen gør.

\section{HVAD ER SPROG?}

Sproget er noget helt særligt. For det første, er det universelt og enestående for mennesket. Der er ikke noget der svarer til det i dyreriget. For det andet er sprogtilegnelsen (af ens modersmål, ikke andetsprogsindlæring) i hvert fald 
delvist uafhængig af intelligens og kognition generelt. Alle mennesker tilegner sig et eller flere sprog uafhængigt af gode eller dårlige indlæringsevner ( $\mathrm{fx}$ børn med Downs syndrom eller Williams syndrom) eller afvigende psyke (fx skizofreni eller psykopati). For det tredje er sprogtilegnelsen delvist uafhængig af afkodning af statistiske hyppigheder. Det er klart at der er større sandsynlighed for at ord der bruges ofte (fx stedord som dig og mig og den uregelmæssige bøjning af ordet voere), overtages af den følgende generation af sprogbrugere. Så i dette tilfælde spiller statistisk hyppighed en klar rolle, men folk har også intuitioner om strukturer med meget lav hyppighed og endda mulige men ikkeeksisterende ord: Fx er krønefraster ikke et ord i dansk, men det kunne det have været, hvorimod fktoejg ikke er og kunne heller ikke være det. Følgende konstruktion er meget sjælden, Hvor mange blade har du loest $i$ uden at købe først?, men den er grammatisk, mens *Jeg har loest $i$ mange blade uden at købe først ikke er (med mindre der står købe dem først). Der er klar kontrast mellem de to, og det til trods for at den velformede version er yderst sjælden, og at man som hører/læser måske aldrig har hørt konstruktionen før (endsige selve eksemplet). Dertil kommer at mindre børn ikke er dygtige statistikere (det er de fleste voksne for den sags skyld heller ikke), men de er fantastisk dygtige når det kommer til sprogtilegnelse. Kunstige neurale netværker, der skal forestille at modellere hjernen og dens læringsmekanismer, er brillante til afkodning af statistiske træk, men de er meget dårlige til at lære sprog.

Sprog kan naturligvis bruges til kommunikation (eller til at kommunikere noget til nogle og samtidig skjule budskabet for andre, Baker 2003), og det må vel også siges at være sprogets primære funktion. Men det betyder ikke at al kommunikation nødvendigvis er sprog, selvom ordet "sprog" ofte bruges i den forstand, specielt i medierne. Kropssprog, blomsternes "sprog" ("sig det med blomster"), musikkens "sprog", gestik og håndtegn (ikke at forveksle med tegnsprog), og farvernes, tøjets, modens "sprog" osv. Det er ganske rigtigt alt sammen noget man kan kommunikere med, men der er ikke tale om sproglig kommunikation. Der er også forskel på dyrs kommunikationssystemer og menneskets sprog. Selvom sådanne kommunikationssystemer ofte kaldes "dyresprog", er de ret beset "kald", og kald og sprog har forskellige definerende egenskaber (selvom der da også er fælles egenskaber). Fx er kald genetisk kodet og skal ikke læres, mens det er lige omvendt med ord. Kald "peger" (de er indeksikalske) og er således meningsløse uden en fysisk referent (fx advarselskald 
uden trussel). Sproget, derimod, kan bruges både om ting der er langt væk i tid og rum (fx det ydre rum, kosmos, og den fjerne fortid eller fremtid), ting der er usynlige (tro, politik, drømme og ideer), eller for den sags skyld umulige eller ikke-eksisterende ting (rumvæsner, magi, flogiston). (Se Bickerton 2007, Christensen \& Vikner 2009.)

Sproget bruges som sagt oftest til kommunikation og interaktion. Denne interaktion finder naturligvis sted mellem mennesker, men det er lige så selvfølgeligt at det forudsætter individets sproglige kompetence. Sprogprocesseringen, den kognitive eller mentale behandling af sprogligt input og output, finder sted i realtime inde i hjernen hos de enkelte sprogbrugere. Neurolingvistik er studiet i hvordan kognitive sproglige processer er implementeret og organiseret $\mathrm{i}$ hjernen hos individet. (Bemærk at neurolingvistik under ingen omstændigheder skal forveksles med det såkaldte "neurolingvistisk programmering" (NLP)).

Sproget er et kognitivt system, et modul, der kan studeres i isolation (på samme måde som fx åndedrætssystemet og centralnervesystemet er fysiske systemer, moduler, der kan studeres i isolation). I og med at det er en del af kognitionen, indgår sproget $\mathrm{i}$ et større komplekst samspil med andre kognitive systemer og dermed forskellige dele af hjernen. Alt afhængigt af hvordan man definerer hvad sprog er, vil sproget være afhængigt af nogle få områder i hjernen, de såkaldte "sprogområder" i venstre hjernehalvdel, eller involvere langt det meste af hjernen. Den snævreste definition indeholder fonologi, morfologi, syntaks og semantik. Den bredeste definition på sprogsystemet omfatter også de systemer der har med selve forståelsen at gøre, de konceptuelle og intentionelle systemer, herunder pragmatik, og dem der har med artikulation og sprogperception at gøre, herunder fonetik. Det er klart at jo mere man inkluderer i sin definition, jo større dele af hjernen vil være involveret.

\section{HVOR ER MENINGEN?}

Ords betydning aktiverer forskellige dele af hjernen alt afhængig af deres betydning. De rent grammatiske aspekter af et ords betydning, fx ordklasse (verbum, substantiv, adjektiv, etc.), bøjningsendelser (regelmæssig versus uregelmæssig bøjning) og hvilke andre typer af ord det kan kombineres med og hvilke konstruktioner det kan indgå i, er afhængige af områderne omkring 
lateralfuren (det såkaldte perisylviske område) i den venstre hjernehalvdel, der hvor de klassiske "sprogområder" ligger (se Christensen, dette nummer, og Kemmerer \& Gonzalez-Castillo, under udgivelse). Ord som sparke og løbe der betyder noget med benbevægelse, slå og kaste der betyder noget med bevægelse af armene, og smile og tale hvis betydning har med ansigtsbevægelse at gøre, aktiverer områder i hjernen der har at gøre med den rent fysiske bevægelse af henholdsvis benene, armene, og ansigtet. Mens ord for handling eller bevægelse aktiverer motoriske områder, findes effekten af ord med mere visuelle associationer, fx navne på forskellige dyr, i områder i temporallapperne der har med visuel hukommelse at gøre (Pulvermüller 2001). På samme måde giver sætninger der betyder noget med bevægelse i rum, fx Han gik gennem skoven, øget hjerneaktivitet i områder der har med rumlig opfattelse og hukommelse at gøre, mens metaforisk anvendelse, fx Han gik gennem sorgen ikke gør (Wallentin et al. 2005). Desuden kan ord og sætninger, ligesom fx musik, have rent følelsesmæssigt indhold, dvs. have positive eller negative følelsesmæssige associationer, og dermed på forskellig vis aktivere de områder af hjernen der har med vores følelser at gøre (se fx Atchley et al. 2007 og Engels et al. 2007).

\section{DE ENKELTE ARTIKLER}

Thomas Raab giver i sin artikel, "Med humor som våben - sproglig humor som bindeled mellem kognition og emotion", et kort overblik over historiske og sprogvidenskabelige humorteorier og sammenholder dem med en kort gennemgang af udvalgte studier af hjernen og hvordan humor påvirker dens aktiveringsmønstre, og hvordan læsioner påvirker folks evne til at forstå humor. Bl.a. ser det ud til at den højre hjernehalvdel er vigtigt for at forstå pointen i en vittighed. Artiklen handler om det komplekse samspil kognition og emotion og om sproglig humor som bindeled. Sproglig humor består i sin grundform primært af kognitive mekanismer der udløser en emotionel respons. Munterhed er en forudsætning for humoristisk sans og skaber således rammen for humor. Derudover er der en række basale og essentielle komponenter der skal være til stede for at humoren fungerer, dvs. for at det er sjovt. For det første skal der være et element af overraskelse, dvs. en inkongruens (modsætning eller uoverensstemmelse) mellem det vi forventer, og det vi rent faktisk hører eller læser, fx Jeg spurgte bartenderen efter noget koldt med masser af rom i, og han foreslog mig sin kone (hvor man måske ville forvente fx en rom og cola eller en daquiri). 
Der skal også være en vis mængde af potentiel fare eller ubehag. Ved hjælp af sproget fremkaldes fx et ubehag i form af (forståelsen af) social pinlighed, kropsligt ubehag eller spændinger mellem følelser, sex og tabu. Udover at selve det sproglige materiale aktiverer de klassiske sprogområder i venstre hjernehalvdel, viser forsøg også aktivitet som følge af sproglig humor i områder der har med følelser, herunder ubehag, og opfattelsen af sociale situationer at gøre, nemlig i henholdsvis amygdala og insula, og gyrus cingularis anterioris. Thomas Raabs gennemgang viser tydeligt et klart eksempel på hvor sproget har grænseflade til andre kognitive systemer, nemlig det følelsesmæssige (emotionen) og kognition (herunder det at forstå en pointe i en vittighed). Ligesom ord i sig selv kan påvirke aktiviteten i de motoriske områder der har med ordets betydning at gøre (fx bevægelse af arme og ben), kan sproglige udtryk aktivere systemer der har med emotion at gøre, i begge tilfælde systemer der ikke er sproglige.

Mikkel Wallentins bidrag hedder "Er der kønsforskelle i hjernens bearbejdning af sprog?" Hans svar på spørgsmålet er kort og godt: Nej. Mikkel Wallentin gennemgår en lang række undersøgelser af kønsforskelle i sproglige evner og hjerneprocesser. Det hævdes ofte, som regel uden reference, at kvinder er bedre end mænd sprogligt, og at de klarer sig bedst i stort set alle sproglige tests, såsom "verbal fluency", hvor man skal sige så mange ord man kan i forskellige kategorier. En række forsøg har vist at kvinder er markant bedre end mænd, mens andre peger i modsat retning, men store meta-analyser (analyser over analyser), viser at der ikke er nogen statistisk signifikant kønsforskel, mens der er effekter af aldersforskel og uddannelsesniveau. Dertil kommer en statistisk signifikant effekt af kønnet på forfatteren til de forskellige artikler: Kvindelige hovedforfattere er mere tilbøjelige til at rapportere at kvinder klarer sig bedst end mandlige. I undersøgelser af sproglig hukommelse hvor man skal huske så mange ord fra en liste som muligt, klarer kvinder sig bedst. Årsagen hertil er at kvinder synes at gruppere ord i semantiske felter, mens mænd også prøver at huske rækkefølge af ordene. Altså ikke en sproglig forskel, men en forskel i husketeknik.

Det hævdes ofte i medierne at kvinder bruger begge hjernehalvdele mere end mænd, og at forbindelse mellem de to halvdele er størst og indeholder flere forbindelser hos kvinder. En nøje gennemgang af litteraturen viser dog at der 
ikke er nogen forskel i hvor meget eller hvor lidt man bruger henholdsvist den højre, den venstre eller begge hjernehalvdele, og heller ikke nogen forskel i størrelsesforholdet mellem de to hjernehalvdele. Hos begge køn er den venstre hjernehalvdel normalt bedre til sproglige opgaver, og den er en anelse større end den højre. Der er heller ikke nogen overordnet forskel på hjernebjælken der forbinder de to hjernehalvdele. Mikkel Wallentin diskuterer endvidere kønsforskelle i sprogforstyrrelser, udviklingsforstyrrelser, hormonale forstyrrelser og aldring. Konklusionen på denne nøje gennemgang er igen at der ikke findes overbevisende data til at understøtte påstanden om sprogrelaterede kønsforskelle i sproglig kompetence eller i hjernen.

Titlen på Ken Ramshøj Christensens artikel er "Hjernebark og syntaktiske træer". Det er et ordspil der dækker over det faktum at træer, sætninger og hjerner har visse træk tilfælles. Det vigtigste af disse træk er hierarkisk struktur. I sproget kommer det bl.a. til udtryk i syntaksen der er baseret på grundlæggende principper, nemlig generativitet (et forholdsvist lille sæt af regler genererer en sand mangfoldighed af strukturer) og rekursion (fx sætninger inde i sætninger inde i sætninger). Disse to principper ligger også til grund for mange andre ting $\mathrm{i}$ den biologiske verden, såsom vækstmønstre i planter. Selvom sproget deler en række karakteristiske træk med biologiske systemer og andre kommunikationssystemer, er der også træk der ser ud til at være unikke for sproget. Artiklen fokuserer på to af disse træk, nemlig flytning og negation, og hvordan behandlingen (forståelsen) af dem aktiverer forskellige områder i hjernen.

Ordet "flytning" dækker over ordstillingsvariation. Den typiske plads for et objekt er efter verbet (fx ost i Han spiser ost), men fx i $h v$-spørgsmål hvor der spørges til det, står det først i sætningen (fx Hvad spiser han?). Objektet er så at sige blevet flyttet. På samme måde skal et negativt objekt med ingen, ingenting eller intet flytte til en plads midt i sætningen (fx Han har intet spist). Disse to flytninger, $h v$-spørgsmål og "Neg-Shift", har to forskellige funktioner og to forskellige mål. Kort sagt flytter et $h v$-ord til starten af sætningen for at markere at sætningen er et spørgsmål, mens et objekt med fx ingen flytter til negationspladsen midt i sætningen for at markere at sætningen er negativ. $\mathrm{Hv}$ flytning giver øget aktivitet i det klassiske sprogområde kaldet Brocas område, mens Neg-Shift ikke gør. I stedet giver det øget aktivitet i temporallappen. Et 
studie af sætningsnegation (fx Han spiser ikke ost) viser endvidere at syntaktisk struktur som sådan ikke nødvendigvis giver aktivitet i sprogområderne, men i stedet giver aktivitet i præmotoriske områder. Ken Ramshøj Christensen argumenterer for at disse resultater viser at den klassiske model for hvordan sproget er implementeret i hjernen er for simpel. Der er ikke ét sprogområde. Sproget er implementeret som et distribueret system der aktiverer forskellige områder i hjernen alt efter hvilke andre kognitive systemer det skal "snakke med". I studier af hjerne og syntaks afhænger aktiviteten i hjernebarken af "træsorten", dvs. hvordan den syntaktiske struktur ser ud.

Torben Thranes bidrag, "The Language Faculty - Mind or Brain", giver en opsummering af ændringer i centrale antagelser om sprogsystemets interne arkitektur i Chomskys sprogteori siden 1950'erne. Baseret på den amerikanske filosof Frederik Dretskes værker, sætter han sig i en paradoksal situation hvor han på den ene side forsvarer Chomskys generative tilgang som den eneste mulige, mens han på den anden side kritiserer ham for at drage de forkerte konklusioner baseret på tekniske antagelser. En af Chomskys centrale antagelser er at der ikke er noget skel mellem det mentale og det biologiske, dvs. mellem mind og brain, og derfor anvender han termen mind/brain til at henvise til hvad man på dansk kunne kalde kognition/hjerne. At antage det modsatte fører til metodologisk dualisme, dvs. antagelsen at det mentale er af en ganske anden natur end alt andet i det fysiske univers og derfor ikke er underlagt samme objektive videnskabelige metode. Thrane er enig med Chomskys grundantagelse her, men han argumenterer for at termen, mind/brain, har flyttet fokus fra en diskussion af hvad hjernen gør når den behandler sprog, et spørgsmål om funktionalitet, til en diskussion af hvad sprogets system-interne struktur er. Et andet problem er at ordet repræsentation benyttes forskelligt, og at man indenfor generativ grammatik generelt interesserer sig mere for hvordan sådanne repræsentationer genereres, end for hvordan de anvendes. I standard generativ grammatik indeholder syntaktiske repræsentationer blandt andet information om afledningen (derivationen) af strukturen. Thrane argumenterer for at et repræsentationssystem såsom sproget, har som sin dedikerede funktion at bære information om noget andet end sig selv (og sin afledning). Forskellen mellem det Thrane kalder den systemiske og den funktionelle tilgang, beskrives med en analogi til undersøgelsen af et kamera og dets output, et fotografi. Chomskys tilgang er at det eneste relevante der kan udledes af undersøgelsen af et kameras 
output, er hvorvidt det understøtter de tekniske specifikationer for kameraets interne opbygning. Dretskes tilgang, derimod, er at det interessante spørgsmål er hvad kameraet skal kunne, for at der i det hele taget kan være et output, dvs. for at tage et fotografi.

\section{LITTERATUR}

Atchley, Ruth Ann, Stephen S. Ilardi, Aubrey Enloe (2007), "Hemispheric Asymmetry in the Processing of Emotional Content in Word Meanings: The Effect of Current and Past Depression" i: Brain and Language, 84, pp. 105-119.

Baker, Mark (2003), "Linguistic Differences and Language Design" i: Trends in Cognitive Sciences, 7/8, pp. 349-353.

Bickerton, Derek (2007), "Language Evolution: A brief Guide for Linguists" i: Lingua, 117, pp. 510-526.

Christensen, Ken Ramshøj, Sten Vikner (2009), "Sprog og evolution" i: Kjærgaard, Peter (red.), evolution.dk, http://evolution.dk/evolutiondk/evolution/evolution-overalt/sprog.html

Engels, Anna, Wendy Heller, Aprajita Mohanty, John D. Herrington, Mariet Banich, Andrew G. Webb, Gregory A. Miller (2007), "Specificity of Regional Brain Activity in Anxiety Types During Emotion Processing" i: Psychophysiology, 44, pp. 352-363.

Kemmerer, David, Javier Gonzalez-Castillo (2010), "The Two-Level Theory of Verb Meaning: An Approach to Integrating the Semantics of Action with the Mirror Neuron System" i: Brain and Language, 112 (1), pp. 54-76.

Pulvermüller, Friedemann (2001), "Brain Reflections of Words and their Meaning" i: Trends in Cognitive Sciences, 5.12, pp. 517-524.

Wallentin, Mikkel, Svend Østergaard, Torben Ellegaard Lund, Leif Østergaard, Andreas Roepstorff (2005), "Concrete Spatial Language: See What I Mean?" i: Brain and Language, 92, pp. 221-233. 